\title{
Phytochemical profiling of phytoconstituents of grape, Jatropha curcas and Neem (Azadirachta indica) extracts
}

\author{
Olabinri B. M.*, Adepoju E. A., Zainab A. A. and Ahmed A. A. \\ Department of Biochemistry, Ladoke Akintola University of Technology, Ogbomoso, Nigeria.
}

Accepted 16 December, 2013

\begin{abstract}
This study investigated the phytoconstituents in Neem (seed and flower), Jatropha curcas (stem and root bark) and grape (stem bark and leaves) in some selected solvents. Phytochemical screening revealed the presence of bioactive compound saponin in all the parts of the three plants in water extract only. Saponin was absent in other solvents used (ethanol, ethyl acetate, propan-2-ol, methanol, nbutanol and acetone). Ethanol, ethyl acetate and methanol were the most promising solvents to extract flavonoids in both the seed and flower of Neem plant. Acetone and ethanol were the most promising solvents to extract flavonoids in the stem bark of $J$. curcas. In the root bark of $J$. curcas, acetone and ethyl acetate were the most promising solvents to extract flavonoids. In grape (Citrus paradisi) leaves, ethanol, water and acetone were the most promising solvents to extract flavonoids. In the stem bark of grape, water, ethyl acetate and acetone proved promising as extraction solvents for flavonoids. All the parts of the plants studied were positive for alkaloid in ethanol and acetone extracts. The seed extract of Neem (Azadirachta indica) was strongly positive in ethanol only. Terpenoids were detected in ethyl acetate and $n$-butanol in all the parts of the three plants. Aged flower extract of Neem plant with pale pink colour could be exploited as a novel source of colourant. Volatile oil was not restricted to J. curcas stem and root barks, it was also present in $C$. paradisi stem and root barks. The nutritional significance, economic and toxicological implications of phytoconstituents analysed in the plants were discussed.
\end{abstract}

Key words: Phytomedicine, bioactive compounds, natural product, drug discovery, preventive medicine.

\section{INTRODUCTION}

Plant extracts or secondary metabolites have served as antioxidants in phytotherapeutic medicines to protect against various diseases for centuries (Halliwell, 1996). The grape fruit (Citrus paradisi) is a subtropical citrus tree known for its bitter fruit (Sean and Henry, 2003). Grape contains many bioactive constituents such as flavonoids, polyphenols, anthocyanins and stilbene derivatives of resveratrol (Cetin and Sagdic, 2009). Grape fruit mercaptan, a sulphur-containing terpene, is one of the substances which have a strong influence on the taste and odour of grape fruit (Buettner and Schieberle, 1999). Grape is used in the treatment of $B$ and $C$ type viral hepatitis
(Block et al., 1994). Grape oil is used in aromatherapy, and its historically known for its aroma (Ann, 1991). The seeds have antioxidant (Yigit et al., 2009) and cardioprotective (Falchi et al., 2006) properties. The grape seed extract displayed reduction of platelet adhesion and aggregation and generation of superoxide radical (Olas et al., 2008).

The utility of Jatropha curcas oil and its esters as replace-ment for petrodiesel is well documented (Roach et al., 2012; Kywe and Oo, 2009). The seed oil of the plant is rich in phorboesters (Roach et al., 2012). The antifungal effect of the seeds is due to its phorbol esters 
(Saetea and Suntornsuk, 2010). The fruit possessed abortifacient property (Goonasekera et al., 1995). The latex and leaf extracts of the J. curcas showed the highest in vitro antioxidant activity and the extracts of different plant parts contained various levels of phenolics, flavonoids and saponins (Oskoueian et al., 2011; Sawant and Joshi, 2010). Saponin isolated from the plant is useful in managing inflammation (Just et al., 1998). The aqueous branch extract of the plant inhibited HIV-1 (Matsuse et al., 1999).

Azadirachta indica (Neem) belongs to the mahogamy family (Meliaceae) (Girish and Shankora, 2008). The leaf powder of $A$. indica is used as a biosorbent for the removal of congo red from water (Bhattacharyya and Sarma, 2003). Tignic acid is responsible for the bitter taste of the seed oil (Lale, 2002). Beta-nimbolides, flavonoids and carotenoids are the constituents of the flower of $A$. indica (Srithanaudomchai et al., 2005). The genotoxic effect of the plant is due to the most active principle (azadirachtin) (Khan and Aswathy, 2003). Neem oil is an indigenous product and a practical solution to curtail mosquito nuisance (Mishra et al., 1995).

The phytochemical screening of the aqueous, ethanolic and methanolic extracts of the $J$. curcas has been reported (Igbinosa et al., 2009), but the authors failed to categorize the bioactive compounds in the three solvents. The methanolic leaf extract of the plant revealed the presence of bioactive compounds like flavonoids, tannins, alkaloids, saponin, steroids and triterpenoids (Uche and Aprioku, 2008). Sharma et al. (2012) reported the presence of bioactive compounds such as alkaloids, saponins, tannins, terpenoids, steroids, glycosides, phenols and flavnoids in the extracts of root, stem and leaf of the plant in one solvent only (methanol), but failed to utilize several solvents. Daniel et al. (2012) reported the bioactive principles in the leaves, bark and seed extracts of the plant using methanol alone, but failed to use many solvents.

This study was designed to add more knowledge to the bioactive compounds in several solvents (seven solvents), which include water, ethanol, ethyl acetate, nbutanol, propan-2-ol, methanol and acetone.

\section{MATERIALS AND METHODS}

\section{Collection of plant}

The seeds and flowers of Neem ( $A$. indica) were collected from the premises of Ladoke Akintola University of Technology, Ogbomoso, Nigeria on the 14th of February, 2010. The root and stem barks of J. curcas was collected from Oke-Anu area of Ogbomoso, Nigeria on the 6th March, 2010. The stem bark and leaves of grape fruit plant was collected from the premises of Soun High School, Ikuye, Ogbomoso, North Local Government, Ogbomoso, Nigeria on the 14th March, 2010.

\section{Phytochemical analysis}

The phytochemical analysis was carried according to standard methods (Parekh and Chanda, 2006; Trease and Evans, 2002; Sofowora, 1993; Harborne, 1973) with little modification. For qualitative test for alkaloid, Wagner's test was utilized. To $1 \mathrm{ml}$ of extract, $1 \mathrm{ml}$ of $1 \% \mathrm{HCl}$ was added and the mixture steamed in a water bath. To the solution, 6 drops of Wagner's reagent was added. Formation of brownish precipitate is indicative of alkaloids.

For flavonoid detection, Shibata's test was used, and it involved the addition of $0.4 \mathrm{ml}$ of concentrated $\mathrm{HCl}$ to $1 \mathrm{ml}$ of extract, followed by the addition of few pieces of magnesium ribbon. Pink colour indicates the formation of flavonoid. Volatile oil was detected in the extract by the addition of $0.1 \mathrm{ml} \mathrm{NaOH}$ solution to $1 \mathrm{ml}$ of extract, followed by small quantity of dilute $\mathrm{HCl}$. A white precipitate indicates the presence of volatile oil. Frothing test was employed for the qualitative identification of saponin. To $2 \mathrm{ml}$ extract, $2 \mathrm{ml}$ of distilled water was added and the mixture shaken. Pesistent/stable foam was used to detect saponin.

Tannin in the extract was detected by adding few drops of $0.1 \%$ $\mathrm{FeCl}_{3}$ to $1 \mathrm{ml}$ extract. Bluish black indicates tannin. For phlobatanin detection, $1 \mathrm{ml}$ of $1 \% \mathrm{HCl}$ was added to $1 \mathrm{ml}$ extract and the mixture was steamed in a water bath for $10 \mathrm{~min}$. Formation of a red precipitate indicates phlobatanin. For hydrolysable tannin detection, $2 \mathrm{ml}$ of $10 \%$ ammonia solution was added to $1 \mathrm{ml}$ extract and formation of emulsion indicates the compound. For steroid identification, $1 \mathrm{ml}$ of acetic anhydride was added to $0.5 \mathrm{ml}$ extract, followed by 2 drops of concentrated $\mathrm{H}_{2} \mathrm{SO}_{4}$. Formation of a violet/brown ring at the junction indicates the presence of steroid.

For cardiac glycoside identification, legal test was used. To $1 \mathrm{ml}$ of extract, $0.5 \mathrm{ml}$ of glacial acetic was added, followed by 9 drops of $\mathrm{FeCl}_{3}$ solution, and $0.5 \mathrm{ml}$ of concentration slowly near the side of the test tube. A brown ring at the junction is positive for cardiac glycoside. For cardenolide aglycone, legal test was employed. To 1 $\mathrm{ml}$ of extract, 7 drops of pyridine, 7 drops of $\mathrm{NaOH}$ solution and 7 drops of sodium nitroprusside were added. Formation of a deep red colour that fades to brown indicates cardenolide aglycone.

\section{RESULTS}

Table 1 showed the phytochemical data for flavonoid in different parts of Neem, J. curcas and $C$. paradisi in solvents of interest. The water extracts of $A$. indica and $J$. curcas lacked flavonoid. The leaves and stem bark extracts of $C$. paradisi showed the presence of flavonoid. All the butanol extracts lacked flavonoids in all the parts of the three plants investigated. Acetone proved most promising in the extraction of flavonoid in all the parts of all the plants except the seed of $A$. indica.

Saponin was detected only in the water extract of all the parts of the three plants. Other solvents lacked saponin (Table 2).

Ethanol and acetone were the promising solvents for all the parts of the plant investigated (Table 3 ). Volatile oil was detected in all the parts of C. paradisi, J. curcas and $A$. indica with water, and butanol as separate extraction solvents. Ethyl acetate and ethanol were suitable solvents except that both solvents failed to detect volatile oil in A. indica flower (Table 4).

Cardenolide aglycone was absent in the water, ethanol, ethyl acetate, propan-2-ol in all the parts investigated (Table 5). It was only present in $n$-butanol seed extract of $A$. indica, but absent in other parts. Acetone was the most promising for the detection of the bioactive compound in all parts investigated, except the acetone seed 
Table 1. Flavonoids (Shibata's test).

\begin{tabular}{lcccccc}
\hline \multirow{2}{*}{ Parameter } & \multicolumn{2}{c}{ A. indica } & \multicolumn{2}{c}{ J. curcas } & \multicolumn{2}{c}{ C. paradisi } \\
\cline { 2 - 7 } & Seed & Flower & Stem bark & Root bark & Leaves & Stem bark \\
\hline Water & $-\mathrm{ve}$ & $-\mathrm{ve}$ & $-\mathrm{ve}$ & $-\mathrm{ve}$ & $+\mathrm{ve}$ & $+\mathrm{ve}$ \\
Ethanol & $+\mathrm{ve}$ & $+\mathrm{ve}$ & $+\mathrm{ve}$ & $-\mathrm{ve}$ & $+\mathrm{ve}$ & $-\mathrm{ve}$ \\
Ethyl acetate & $+\mathrm{ve}$ & $+\mathrm{ve}$ & $-\mathrm{ve}$ & $+\mathrm{ve}$ & $-\mathrm{ve}$ & $+\mathrm{ve}$ \\
Propan-2-ol & $-\mathrm{ve}$ & $-\mathrm{ve}$ & $-\mathrm{ve}$ & $-\mathrm{ve}$ & $-\mathrm{ve}$ & $-\mathrm{ve}$ \\
Methanol & $+\mathrm{ve}$ & $+\mathrm{ve}$ & $-\mathrm{ve}$ & $-\mathrm{ve}$ & $-\mathrm{ve}$ & $-\mathrm{ve}$ \\
n-butanol & $-\mathrm{ve}$ & $-\mathrm{ve}$ & $-\mathrm{ve}$ & $-\mathrm{ve}$ & $-\mathrm{ve}$ & $-\mathrm{ve}$ \\
Acetone & $-\mathrm{ve}$ & $+\mathrm{ve}$ & $+\mathrm{ve}$ & $+\mathrm{ve}$ & $+\mathrm{ve}$ & $+\mathrm{ve}$ \\
\hline
\end{tabular}

Table 2. Saponin (Frothing test).

\begin{tabular}{lcccccc}
\hline \multirow{2}{*}{ Parameter } & \multicolumn{2}{c}{ A. indica } & \multicolumn{2}{c}{ J. curcas } & \multicolumn{2}{c}{ C. paradisi } \\
\cline { 2 - 7 } & Seed & Flower & Stem bark & Root bark & Leaves & Stem bark \\
\hline Water & + ve & + -ve & + -ve & + -ve & + -ve & + ve \\
Ethanol & $-v e$ & $-v e$ & $-v e$ & $-v e$ & $-v e$ & $-v e$ \\
Ethyl acetate & $-v e$ & $-v e$ & $-v e$ & $-v e$ & $-v e$ & $-v e$ \\
Propan-2-ol & $-v e$ & $-v e$ & $-v e$ & $-v e$ & $-v e$ & $-v e$ \\
Methanol & $-v e$ & $-v e$ & $-v e$ & $-v e$ & $-v e$ & $-v e$ \\
n-butanol & $-v e$ & $-v e$ & $-v e$ & $-v e$ & $-v e$ & $-v e$ \\
Acetone & $-v e$ & $-v e$ & $-v e$ & $-v e$ & $-v e$ & $-v e$ \\
\hline
\end{tabular}

Table 3. Alkaloid (Wagner's test).

\begin{tabular}{lcccccc}
\hline \multirow{2}{*}{ Parameter } & \multicolumn{2}{c}{ A. indica } & \multicolumn{2}{c}{ J. curcas } & \multicolumn{2}{c}{ C. paradisi } \\
\cline { 2 - 6 } & Seed & Flower & Stem bark & Root bark & Leaves & Stem bark \\
\hline Water & $+\mathrm{ve}$ & $+\mathrm{ve}$ & $+\mathrm{ve}$ & $+\mathrm{ve}$ & $-\mathrm{ve}$ & $+\mathrm{ve}$ \\
Ethanol & Strongly $+\mathrm{ve}$ & $+\mathrm{ve}$ & $+\mathrm{ve}$ & $+\mathrm{ve}$ & $+\mathrm{ve}$ & $+\mathrm{ve}$ \\
Ethyl acetate & Trace & Trace & Trace & Trace & $+\mathrm{ve}$ & Trace \\
Propan-2-ol & $+\mathrm{ve}$ & $+\mathrm{ve}$ & $+\mathrm{ve}$ & $+\mathrm{ve}$ & $-\mathrm{ve}$ & $+\mathrm{ve}$ \\
Methanol & $+\mathrm{ve}$ & $+\mathrm{ve}$ & $+\mathrm{ve}$ & $+\mathrm{ve}$ & Trace & $+\mathrm{ve}$ \\
n-butanol & $+\mathrm{ve}$ & $+\mathrm{ve}$ & $-\mathrm{ve}$ & $-\mathrm{ve}$ & $-\mathrm{ve}$ & $-\mathrm{ve}$ \\
Acetone & $+\mathrm{ve}$ & $+\mathrm{ve}$ & $+\mathrm{ve}$ & $+\mathrm{ve}$ & $+\mathrm{ve}$ & $+\mathrm{ve}$ \\
\hline
\end{tabular}

Table 4. Volatile oil.

\begin{tabular}{lcccccc}
\hline \multirow{2}{*}{ Parameter } & \multicolumn{2}{c}{ A. indica } & \multicolumn{2}{c}{ J. curcas } & \multicolumn{2}{c}{ C. paradisi } \\
\cline { 2 - 7 } & Seed & Flower & Stem bark & Root bark & Leaves & Stem bark \\
\hline Water & $+\mathrm{ve}$ & $+\mathrm{ve}$ & $+\mathrm{ve}$ & $+\mathrm{ve}$ & $+\mathrm{ve}$ & $+\mathrm{ve}$ \\
Ethanol & $+\mathrm{ve}$ & $-\mathrm{ve}$ & $+\mathrm{ve}$ & $+\mathrm{ve}$ & $+\mathrm{ve}$ & $+\mathrm{ve}$ \\
Ethyl acetate & $+\mathrm{ve}$ & $-\mathrm{ve}$ & $+\mathrm{ve}$ & $+\mathrm{ve}$ & $+\mathrm{ve}$ & $+\mathrm{ve}$ \\
Propan-2-ol & $-\mathrm{ve}$ & $+\mathrm{ve}$ & $-\mathrm{ve}$ & $-\mathrm{ve}$ & $-\mathrm{ve}$ & $-\mathrm{ve}$ \\
Methanol & $-\mathrm{ve}$ & $+\mathrm{ve}$ & $-\mathrm{ve}$ & $-\mathrm{ve}$ & $-\mathrm{ve}$ & $-\mathrm{ve}$ \\
n-butanol & $+\mathrm{ve}$ & $+\mathrm{ve}$ & $+\mathrm{ve}$ & $+\mathrm{ve}$ & $+\mathrm{ve}$ & $+\mathrm{ve}$ \\
Acetone & Trace & Trace & $-\mathrm{ve}$ & $-\mathrm{ve}$ & Trace & Trace \\
\hline
\end{tabular}

seed extract of $A$. indica.

Cardiac glycoside was absent in water, ethanol, propan-2-ol and methanol extracts in all the parts investigated (Table 6). Cardiac glycoside was detected in 
Table 5. Cardenolide aglycone (Legal test).

\begin{tabular}{lcccccc}
\hline \multirow{2}{*}{ Parameter } & \multicolumn{2}{c}{ A. indica } & \multicolumn{2}{c}{ J. curcas } & \multicolumn{2}{c}{ C. paradisi } \\
\cline { 2 - 7 } & Seed & Flower & Stem bark & Root bark & Leaves & Stem bark \\
\hline Water & $-v e$ & $-v e$ & $-v e$ & $-v e$ & $-v e$ & $-v e$ \\
Ethanol & $-v e$ & $-v e$ & $-v e$ & $-v e$ & $-v e$ & $-v e$ \\
Ethyl acetate & $-v e$ & $-v e$ & $-v e$ & $-v e$ & $-v e$ & $-v e$ \\
Propan-2-ol & $-v e$ & $-v e$ & $-v e$ & $-v e$ & $-v e$ & $-v e$ \\
Methanol & $-v e$ & $-v e$ & $-v e$ & $-v e$ & $-v e$ & $-v e$ \\
n-butanol & $+v e$ & $-v e$ & $-v e$ & $-v e$ & $-v e$ & $-v e$ \\
Acetone & $-v e$ & $+v e$ & $+v e$ & $+v e$ & $+v e$ & $+v e$ \\
\hline
\end{tabular}

Table 6. Cardiac glycoside.

\begin{tabular}{lcccccc}
\hline \multirow{2}{*}{ Parameter } & \multicolumn{2}{c}{ A. indica } & \multicolumn{2}{c}{ J. curcas } & \multicolumn{2}{c}{ C. paradisi } \\
\cline { 2 - 7 } & Seed & Flower & Stem bark & Root bark & Leaves & Stem bark \\
\hline Water & $-v e$ & $-v e$ & $-v e$ & $-v e$ & $-v e$ & $-v e$ \\
Ethanol & $-v e$ & $-v e$ & $-v e$ & $-v e$ & $-v e$ & $-v e$ \\
Ethyl acetate & Positive & $-v e$ & $-v e$ & $-v e$ & $-v e$ & $-v e$ \\
Propan-2-ol & $-v e$ & $-v e$ & $-v e$ & $-v e$ & $-v e$ & $-v e$ \\
Methanol & $-v e$ & $-v e$ & $-v e$ & $-v e$ & $-v e$ & $-v e$ \\
n-butanol & + -ve & $-v e$ & $-v e$ & $-v e$ & $-v e$ & $-v e$ \\
Acetone & $-v e$ & $-v e$ & +ve & $+v e$ & $+v e$ & $+v e$ \\
\hline
\end{tabular}

Table 7. Tannin.

\begin{tabular}{lcccccc}
\hline \multirow{2}{*}{ Parameter } & \multicolumn{2}{c}{ A. indica } & \multicolumn{2}{c}{ J. curcas } & \multicolumn{2}{c}{ C. paradisi } \\
\cline { 2 - 7 } & Seed & Flower & Stem bark & Root bark & Leaves & Stem bark \\
\hline Water & trace & Trace & $-v e$ & Trace & Trace & Trace \\
Ethanol & $-v e$ & $+v e$ & $+v e$ & $+v e$ & $+v e$ & $+v e$ \\
Ethyl acetate & $-v e$ & $-v e$ & $-v e$ & $-v e$ & $-v e$ & $-v e$ \\
Propan-2-ol & $-v e$ & $-v e$ & $-v e$ & $-v e$ & $-v e$ & $-v e$ \\
Methanol & $-v e$ & $-v e$ & $-v e$ & $-v e$ & $-v e$ & $-v e$ \\
n-butanol & $-v e$ & $-v e$ & $-v e$ & $-v e$ & $-v e$ & $-v e$ \\
Acetone & $-v e$ & $-v e$ & $-v e$ & $-v e$ & $+v e$ & $-v e$ \\
\hline
\end{tabular}

the stem and root acetone extract in J. curcas and $C$. paradisi.

Tannin was absent in the ethyl acetate, propan-2-ol, methanol and n-butanol extracts of all the parts of the three plants (Table 7). Tannin was positive in ethanolic extracts of the parts of the plants except the ethanolic seed extract of $A$. indica.

Hydrolysable tannin was present in n-butanol and ethyl acetate extracts of the three plants. Phytochemical screening showed the absence of hydrolysable tannin in water, ethanol, propan-2-ol, methanol and acetone extracts (Table 8).

Phytochemical screening revealed that steroid was strongly positive in methanolic flower extract of $A$. indica (Table 9). The aqueous, ethyl acetate, propan-2-ol and acetone extracts in all the parts of the plants lacked steroid.

Terpenoid was positive in ethyl acetate and n-butanol extracts in all the parts of the plants. The aqueous, ethanol, propan-2-ol and methanolic extracts lacked terpenoid in all the parts of the three plants.

Phlobatanin was only positive in methanolic leaf extract of $C$. pardisi (Table 11). Meth indicates methanol, while $\mathrm{n}$-butan and pro indicate n-butanol and propan-2-ol, respectively. After 20 days of soaking, saponin was present in both the Neem flower and seed extracts. Flavonoid and 
Table 8. Hydrolysable tannin.

\begin{tabular}{lcccccc}
\hline \multirow{2}{*}{ Parameter } & \multicolumn{2}{c}{ A. indica } & \multicolumn{2}{c}{ J. curcas } & \multicolumn{2}{c}{ C. paradisi } \\
\cline { 2 - 7 } & Seed & Flower & Stem bark & Root bark & Leaves & Stem bark \\
\hline Water & $-v e$ & $-v e$ & $-v e$ & $-v e$ & $-v e$ & $-v e$ \\
Ethanol & $-v e$ & $-v e$ & $-v e$ & $-v e$ & $-v e$ & $-v e$ \\
Ethyl acetate & $+v e$ & $+v e$ & $+v e$ & $+v e$ & $+v e$ & $+v e$ \\
Propan-2-ol & $-v e$ & $-v e$ & $-v e$ & $-v e$ & $-v e$ & $-v e$ \\
Methanol & $-v e$ & $-v e$ & $-v e$ & $-v e$ & $-v e$ & $-v e$ \\
n-butanol & $+v e$ & $+v e$ & $+v e$ & $+v e$ & $+v e$ & $+v e$ \\
Acetone & $-v e$ & $-v e$ & $-v e$ & $-v e$ & $-v e$ & $-v e$ \\
\hline
\end{tabular}

Table 9. Steroids.

\begin{tabular}{|c|c|c|c|c|c|c|}
\hline \multirow{2}{*}{ Parameter } & \multicolumn{2}{|c|}{ A. indica } & \multicolumn{2}{|c|}{ J. curcas } & \multicolumn{2}{|c|}{ C. paradisi } \\
\hline & Seed & Flower & Stem bark & Root bark & Leaves & Stem bark \\
\hline Water & -ve & -ve & -ve & -ve & -ve & -ve \\
\hline Ethanol & -ve & + ve & -ve & -ve & -ve & -ve \\
\hline Ethyl acetate & -ve & -ve & -ve & -ve & -ve & -ve \\
\hline Propan-2-ol & -ve & -ve & -ve & -ve & -ve & -ve \\
\hline Methanol & Trace & Strongly +ve & Trace & Trace & trace & Trace \\
\hline n-butanol & -ve & + ve & -ve & -ve & -ve & -ve \\
\hline Acetone & -ve & -ve & -ve & -ve & -ve & -ve \\
\hline
\end{tabular}

Table 10. Terpenoid.

\begin{tabular}{lcccccc}
\hline \multirow{2}{*}{ Parameter } & \multicolumn{2}{c}{$\boldsymbol{A}$. indica } & \multicolumn{2}{c}{ J. curcas } & \multicolumn{2}{c}{ C. paradisi } \\
\cline { 2 - 7 } & Seed & Flower & Stem bark & Root bark & Leaves & Stem bark \\
\hline Water & $-\mathrm{ve}$ & $-\mathrm{ve}$ & $-\mathrm{ve}$ & $-\mathrm{ve}$ & $-\mathrm{ve}$ & $-\mathrm{ve}$ \\
Ethanol & $-\mathrm{ve}$ & $+\mathrm{ve}$ & $-\mathrm{ve}$ & $-\mathrm{ve}$ & $-\mathrm{ve}$ & $-\mathrm{ve}$ \\
Ethyl acetate & $+\mathrm{ve}$ & $+\mathrm{ve}$ & $+\mathrm{ve}$ & $+\mathrm{ve}$ & $+\mathrm{ve}$ & $+\mathrm{ve}$ \\
Propan-2-ol & $-\mathrm{ve}$ & $-\mathrm{ve}$ & $-\mathrm{ve}$ & $-\mathrm{ve}$ & $-\mathrm{ve}$ & $-\mathrm{ve}$ \\
Methanol & $-\mathrm{ve}$ & $-\mathrm{ve}$ & $-\mathrm{ve}$ & $-\mathrm{ve}$ & $-\mathrm{ve}$ & $-\mathrm{ve}$ \\
n-butanol & $+\mathrm{ve}$ & $+\mathrm{ve}$ & $+\mathrm{ve}$ & $+\mathrm{ve}$ & $+\mathrm{+ve}$ & $+\mathrm{ve}$ \\
Acetone & Trace & Trace & Trace & Trace & Trace & Trace \\
\hline
\end{tabular}

Table 11. Phlobatatannin.

\begin{tabular}{|c|c|c|c|c|c|c|}
\hline \multirow{2}{*}{ Parameter } & \multicolumn{2}{|c|}{ A. indica } & \multicolumn{2}{|c|}{ J. curcas } & \multicolumn{2}{|c|}{ C. paradisi } \\
\hline & Seed & Flower & Stem bark & Root bark & Leaves & Stem bark \\
\hline Water & trace & Trace & -ve & - & Trace & Trace \\
\hline Ethanol & -ve & -ve & -ve & - & -ve & -ve \\
\hline Ethyl acetate & Trace & Trace & -ve & - & Trace & Trace \\
\hline Propan-2-ol & -ve & -ve & trace & - & -ve & -ve \\
\hline Methanol & -ve & -ve & -ve & - & $+\mathrm{ve}$ & -ve \\
\hline n-butanol & -ve & -ve & -ve & - & -ve & -ve \\
\hline Acetone & -ve & -ve & -ve. & - & -ve & -ve \\
\hline
\end{tabular}


Table 12. Phytochemical screening of Neem (Azadirachta indica) seed and flower extracts.

\begin{tabular}{lcccccccccc}
\hline \multirow{2}{*}{ Parameter } & \multicolumn{3}{c}{ Seed extract after 20 days of soaking } & \multicolumn{4}{c}{ Flower extract after 20 days of soaking } \\
\cline { 2 - 11 } & Water & ethanol & Meth & n-butan & prop & water & ethanol & Methanol & n-butanol & Prop \\
\hline Tannin & $-v e$ & $-v e$ & $-v e$ & $-v e$ & $-v e$ & $-v e$ & $-v e$ & $-v e$ & $-v e$ & $-v e$ \\
Flavonol & $-v e$ & $-v e$ & $-v e$ & $-v e$ & $-v e$ & $-v e$ & Trace & $-v e$ & $-v e$ & $-v e$ \\
Saponin & $+v e$ & $-v e$ & $-v e$ & $-v e$ & $-v e$ & $+v e$ & $-v e$ & $-v e$ & $-v e$ & $-v e$ \\
\hline
\end{tabular}

tannin were absent in seed and flower extracts of Neem plant after 20 days of soaking (Table 12).

\section{DISCUSSION}

In this study, phytochemical screening revealed the presence of bioactive compound alkaloid in the stem and root of $J$. curcas in methanol, which is consistent with the finding of Sharma et al. (2012). However, this study failed to detect the presence of flavonoids, saponin and cardiac glycosides, terpenoids and tannin in the methanolic extracts of the root and stem of the plant, while Sharma et al. (2012) detected the presence of the bioactive compounds. Phytochemicals are chemical compounds formed during the plants normal metabolic processes; these chemicals are often referred to as secondary metabolites of which there are several classes including alkaloids, flavonoids, coumarins, glycosides, polysaccharides, phenols, tannins, terpenes and terpenoids (Okwu, 2004).

In this work, flavonoid was detected in the methanolic seed extract of $A$. indica, which is in agreement with the earlier investigation (Daniel et al., 2012). The two bioactive compounds (saponin and tannin) previously identified with methanol as extraction solvent in other laboratory (Daniel et al., 2012) were not detected in the present study. In this study, alkaloid in the methanolic seed extract of $A$. indica was detected, which was not consistent with the work of Daniel et al. (2012). Methanol and ethanol have been proved as effective solvents to extract phenolic compounds (Siddhuraju et al., 2003).

Water was a promising solvent for the extraction of bioactive compounds like flavonoids, cardiac glycosides and terpenoids for the leaf of $A$. indica (Selvan et al., 2012), but the same solvent failed to detect these bioactive compounds in $A$. indica flower in this work. Moreover, saponin was detected in the water flower extract of the plant. .Saponin had earlier been reported to be present in the water extract of $A$. indica leaf (Selvan et al., 2012).

Saponins are amphipathic glycosides grouped phenomenologically by the soap-like foaming they produce when shaked in aqueous solutions (Hostettmann and Marston, 1995). Most saponins function as antioxidants, because they possess a special moiety (2,3-dihydri-2,5 -dihyroxy6-methyl-4-pyran -4-one) which act by forming hydroperoxide intermediates thus removing free radicals (Hu et al., 2002). Saponins possesss haemolytic action on human erythrocytes (Baumann et al., 2000). Saponins with acyl residues or oxide-ring moiety tend to show haemolytic activity (Oda et al., 2000).

Flavonoids are important in human diet and are present in plant extracts that have been used for centuries in oriental medicine ( $\mathrm{Di}$ Carlo et al., 1999). Antioxidant properties, reactive oxygen species scavenging, and cell function modulation of flavonoids could account for the large part of their pharmacological activity (Limasset et al., 1993).

Raw oil of J. curcas has been used as a substitute for petrol-diesel both in modified and unmodified diesel engines (Jingura et al., 2010). J. curcas plant found in Nigeria has the potential of boosting the economy in term of biodiesel production (Belewu et al., 2010). n-Hexane may be preferable in the extraction of biodiesel oil from $\mathrm{J}$. curcas (Belewu et al., 2010), although petroleum ether had been used with lower yield (Adebayo et al., 2011).

Some alkaloids are known to precipitate hepatocyte necrosis and cytoskeleton disorganization (Lekhehal et al., 1996). Phenolic alkaloids such as caffeic acid phenyl ester (CAPE) have been reported to possess beneficial effects such as anti-tumor property against human breast cancer line (Grunberger et al., 1988) and in the treatment of acute inflammation (Orban et al., 2000).

Cardiac glycosides are class of natural product, which are used to increase the cardiac contractile force in patients with congestive heart failure and cardiac arrhythmias (Hauptman et al., 1999).

In this work, the water flower extract of $A$. indica afforded pale colour after 20 days of soaking in water. The water flower extract of the plant could be exploited as a colourant, although with caution. The aqueous flower extract with pale colour was positive for saponin. This requires future research. This could be due to browning process. The enzymatic oxidation of polyphenols, particularly, flavonoids, occurs during storage when cell integrity is affected (Cheynier, 2005, 1994). Flavonoids, particularly, ortho-diphenols, can be oxidized to their corresponding semiquinones and quinones by oxidases such as polyphenol oxidase and peroxidases (Yoruk and Marshall, 2003; Walker and Ferrar, 1998). 


\section{REFERENCES}

Adebayo GB, Ameen OM, Abass LT (2011). Physicochemical properties of biodiesel produced from Jatropha curcas and fossil diesel. J. Microbiol. Biotechnol. Res. 1(1):12-16.

Ann WV (1991). The complete book of essential oils and aromatherapy. Navato: California pp. 84-87.

Baumann E, Stoya G, Volkner A, Richter W, Lemke C, Linss W (2000). Haemolysis of human erythrocyte with saponin affects the membrane structure. Acta Histochemica 102(1):21-35.

Belewu MA, Adekola FA, Adebayo GB, Ameen OM, Muhammed NO, Olaniyan AM, Adekola OF, Musa AK (2010). Physico-chemical characteristics of oil and biodiesel from Nigerian and Indian Jatropha curcas seeds. Int. J. Biol. Chem. 4(2):524-529.

Bhattacharyya KG, Sarma A (2003). Adsorption characteristics of the dye, brilliant green on Neem leaf. Dyes Pigm. 57:211-222.

Buettner A, Schieberle P (1999). Characterization of the most odouractive volatiles in fresh, hand -squeezed juice of Grape fruit (Citrus paradisi Macfayden). J. Agric. Food Chem. 47(12):5189-5193.

Cetin A, Sagdic O (2009). A concise review: antioxidant effects and bioactive constituents of grape. Erciyes Tip Dergisib Online 31(4):369-375.

Cheynier V (1994). Anthocyanin degradation in oxidizing grape musts. J. Sci. Food Agric. 66:283 -288.

Cheynier V (2005). Polyphenols in foods are more complex than often thought. Am. J. Clin. Nutr. 81:223S-229S.

Daniel UN, Ohalete CN, Nnoli MC (2012). Phytochemical screening for active compounds in leaves, bark and seed extracts of Azadirachta indica in Owerri, Imo State, South -Eastern Nigeria. World J. Pharm Pharm. Sci. 1(4):1181-1188.

Di Carlo G, Mascolo N, Izzo AA, Capasso F (1993). Flavonoids: old and new aspects of a class of natural therapeutic drugs. Life Sci. 64(4):337-353.

Falchi M, Bertelli A, Scarlzo RL, Morassut M, Morelli R, Das S, Cui JH, Das DK (2006). Comparison of cardio protective abilities between the flesh and skin of grapes. J. Agric. Food Chem. 54:6613-6622.

Goonasekera MM, Gunawardana VK, Jayasena K, Mohammed SG, Balasubramaniam S (1995). Pregnancy termination effect of Jatropha curcas in rats. J. Ethnopharmacol. 47:117-123.

Grunberger D, Banerjee R, Eisinger K, Oltz EM, Efros L, Caldwell M, Estevez V, Nakanishi K (1988). Preferential cytotoxicity on tumor cells by caffeic acid phenethyl ester isolated from propolis. Experientia 44(3):230-232.

Halliwell B (1996). Antioxidants in human health and disease. Ann. Rev. Nutr. 16:33- 50

Harborne JB (1973). Phytochemical Methods. $3^{\text {rd }}$ Ed. Chapman and Hall, London. pp. $41-48$.

Hauptman PJ, Garg R, Kelly RA (1999). Cardiac glycosides in the next millennium. Prog. Cardiovasc. Dis. 41: $247-254$.

Hostettmann K, Marston A (1995). Saponins Chemistry and Pharmacology of National Products. University Press Cambridge. P 560.

Hu J, Lee SO, Hendrich S, Murphy PA (2002). Quantification of the group $B$ soya saponins by high performance liquid chromatography. J. Agric. Food Chem. 50:2587-2594.

Igbinosa OO, Igbinosa EO, Aiyegoro OA (2009). Antimicrobial activity and phytochemical screening of stem bark extracts from Jatropha curcas (Linn). Afr. J. Pharm. Pharmacol. 3(2):058-062.

Jingura R, Musademba $D$, Matengaifa $R$ (2010). An evaluation of utility of $J$. curcas L. as a source of multiple energy carriers. Int. J. Eng. Sci. Tech. 2(7):115-122.

Just MJ, Recio M, Giner RM, Cueller MJ, Manez S, Billia AR, Rios JL (1998). Anti-inflammatory of unusual lupine saponins from Bupleurum fruticescens. Planta Medica 64:404-407.

Khan PK, Awasthy KS (2003). Cytogenetic toxicity of neem oil. Food Chem. Toxicol. 41(10):132-138.

Kywe TT, Oo MM (2009). Production of biodiesel from Jatropha oil (Jatropha curcas) in pilot plant. Proc. World Acad. 38:481-487.

Lale NES (2002). Bioactivity and limitation against widespread use of neem products for the management of insect pests. Niger. J. Appl. Biol. 3:115-124.
Lekhehal M, Pessayre D, Lereau JM, Moulis C, Fouraste F, Fau D (1996). Hepatoxicity of the herbal medicine germander. Metabolic activation of its furano diterpenoids by cytochrome P450 3A depletes cytoskeleton associated protein thiols and forms plasma membrane bebs in hepatocytes. Hepatology 24:212 -221.

Limasset B, Doucen CL, Dore JC, Ojasoo T, Damon M, Paulet AC (1993). Effects of flavonoids on the release of reactive oxygen species by stimulated human neutrophils. Biochem. Pharmacol. 46:1257-1271.

Matsuse TI, Lim YA, Hattori M, Correa M, Gupta MP (1999). A search for anti-viral properties in Panamanian medicinal plants. The effect on HIV and essential enzymes. J. Ethnopharmacol. 64:15-22.

Mishra AK, Singh N, Sharma VP (1995). Use of neem oil as a mosquito repellent in tribal villages of Mandla district, India. J. Malariol. 32(3):99-103.

Oda K, Matsuda H, Murakami T, Katayama S, Ohgitani T, Yoshikawa M (2000). Adjuvant and haemolytic activities of 47 saponins derived from medicinal and food plants. Biol. Chem. 381(1):6 -74.

Olas B, Wachowicz B, Tomczak A, Erler J, Stochmal A, Oleszek W (2008). Comparative anti-platelet and antioxidant properties of polyphenol-rich extracts from berries, seeds of grape and bark of Yucca schidigera in vitro. Platelets 19:70-77.

Orban Z, Mitsiades N, Burke TR (Jr), Tsokos M, Chrousos GP (2000). Caffeic acid phenyl ester induces leucocyte apoptosis, modulate nuclear factor -kappa $B$ and suppresses acute inflammation. Neuroimmunodulation 7(2):99:105.

Oskoueian E, Abdullahi N, Saad WZ, Omar AR, Ahmad S, Kuan WB, Zolkifli NA, Hendra R, Ho YW (2011). Antioxidant, anti-inflammatory and anticancer activities of methanolic extracts from Jatropha curcas Linn. J. Med. Plant Res. 5(1):49-57.

Parekh J, Chandas (2006). In vitro antimicrobial activities of extract of Launea procumbens. Roxb (Labiateae), Vitis vinifera (Vitaceae) and Cyperus rotundus (Cyperaceae). Afr. J. Biomed. Res. 9:89-93.

Roach JS, Devappa RK, Makkar HPS, Becker K (2012).Isolation, stability and bioactivity of Jatropha curcas phorbol esters. Fitoterapia 83(3):586-592.

Saetae D, Suntornsuk W (2010). Antifungal activities of ethanolic extract from Jatropha curcas seed cake. J. Microbiol. Biotechnol. 20(2):319-324.

Sawant HP, Joshi YM (2010). In vitro antioxidant activity of hydro alcoholic extracts of the leaves of Jatropha curcas Linn. J. Pharm Res 3(4):883-886.

Sean C, Henry F (2003). Grape fruit b.A-Z of Bardos Heritage. Macmillan, Carrbbean. pp. 90 -91.

Selvan TR, Mohideen AKS, Sheriff MA, Azmathullah NM (2012). Phytochemical screening of Acalypha indica L. leaf extracts. Int. J. Apppl. Biol. Pharm. Technol. 3(2):158-161.

Sharma AK, Gangwar M, Tilak R, Nath G, Sinha ASK, Tripathi YB, Kumar DC (2012).Comaparative in vitro antimalarial and phytochemical evaluation of methanolic extract of root, stem and leaf of Jatropha curcas Linn. Intl. J. Pharm. Sci. Res. 3(6):154-1553.

Siddhuraju P, Mohan PS, Becker K (2002). Studies on the antioxidant activity of Indian Laburnum (Cassia fistula L): a preliminary assessment of crude extracts from stem bark leaves, flowers and fruit pulp. Food Chem. 79:61-67.

Sofowora A (1993). Medicinal plants and traditional medicine in Africa. $2^{\text {nd }}$ Edition. Spectrum Books Ltd, Ibadan, Nigeria: pp 134-156.

Srithanaudomchai $\mathrm{H}$, Kuoamaran T, Kuakulkiat W, Bunyapraphatsara N, Hiransalee A, Tepsuwan A and Kuramiran WR (2005). Quinine reductase inducers vin Azadirachta indica A. Just flowers, and their mechanisms of action. Asian Pac. J. Cancer Prev. 6(3):263-269.

Trease GE, Evans WC (2002). Pharmacognosy. 15 ${ }^{\text {th }}$ Ed.London: Saunders Publishers. pp. 42-393.

Walker JR, Ferrar PH (1994). Diphenol oxidases, enzyme catalysed browning and plant disease resistance. Biotechnol. Genet. Eng. Rev.15:457-498.

Yigit D, Yigit N, Mavi A, Yildirim A, Guleryuz M (2009). Antioxidant and antimicrobial activities of methanol and water extract of fruits, leaves and seeds of Vitis vinifera L. cv. Karaerik. Asia. J. Chem. 21:183-194.

Yoruk R, Marshall MR (2003). Physicochemical properties and function of plant polyphenol oxidase: a review. J. Food Biochem. 27:361-422. 